\title{
A Biocompatible Needle-Type Glucose Sensor Based on Platinum- Electroplated Carbon Electrode
}

\author{
CHIEN-YUAN CHEN, ${ }^{*, 1,2}$ EIICHI TAMIYA, ${ }^{1}$ \\ KAZUHIKO ISHIHARA, ${ }^{4}$ YUKIO KOSUGI, ${ }^{3}$ YUAN-CHI SU, ${ }^{2}$ \\ NOBUO NAKABAYASHI, ${ }^{4}$ AND ISAO KARUBE ${ }^{1}$
}

${ }_{1}^{1}$ Research Center for Advanced Science and Technology, University of Tokyo, 4-6.1, Komaba, Meguro-Ku, Tokyo 153, Japan; ${ }^{2}$ Department of Agricultural Chemistry, National Taiwan University, 1, Sec. 4, Roosevelt Rd., Taipei, Taiwan, R.O.C.; ${ }^{3}$ Asahi Kento Ind. Co., 2-30, Shukumachi, Minami-Ku, Yokohama-Si, Kanagawa-Ken, Japan; and ${ }^{4}$ Institute for Medical and Dental Engineering, Tokyo Medical and Dental University, 2-3-10, Kanda-Surugadai, Chiyoda-Ku, Tokyo 101, Japan

Received May 20, 1992; Accepted June 29, 1992

\begin{abstract}
A biocompatible needle-type glucose sensor with a 3-electrode configuration was constructed. A platinum-electroplated carbon stick was used as the working electrode, $\mathrm{Ag} / \mathrm{AgCl}$ as the reference electrode, and a disposable hypodermic needle made of stainless steel as the counter electrode. A Nafion membrane, an immobilized glucose oxidase (GOD) membrane, and a biocompatible membrane with diffusion-limiting effect were coated successively onto the working electrode. The sensor showed a rapid response $(<120 \mathrm{~s}$ in batch operation), good reproducibility $(R E<3 \%$ ), good stability (over $36 \mathrm{~h}$ in control serum), a wide dynamic range (5-600 $\mathrm{mg} / \mathrm{dL}$ glucose), and superior biocompatibility. It was used to determine glucose in serum. The data obtained from the sensor showed good agreement with that from a clinical autoanalyzer $(R>0.95)$.
\end{abstract}

*Author to whom all correspondence and reprint requests should be addressed. 
Index Entries: Biocompatibility; 2-methacryloyloxyethyl phosphorylcholine (MPC); n-butylmethacrylate (BMA); cellulose triacetate (CTA); diffusion-limiting effect; glucose sensor; needle type; glucose oxidase; serum.

\section{INTRODUCTION}

Glucose sensors have been studied for some decades and have been well proven. Amperometric glucose enzyme sensors can be divided into three generations (1). The first generation sensors detect $\mathrm{H}_{2} \mathrm{O}_{2}$ formation or $\mathrm{O}_{2}$ consumption during enzymatic reaction. The second generation sensors use a mediator to transfer electrons between the enzyme and the electrode. The third generation sensors have an electrode made from special materials that allow direct transfer of electrons from the enzyme to the electrode. Conductive organic complex salts, such as fulvadene-tetracyanoquinodimethane, have been used as electrode materials for this purpose. Among them, $\mathrm{H}_{2} \mathrm{O}_{2}$-sensing type first generation electrodes are widely used, since $\mathrm{H}_{2} \mathrm{O}_{2}$ is readily oxidized at platinum, gold, and other similar electrode types $(2,3)$.

A needle type sensor seems attractive because it is possible to insert it easily into fruits or biological tissues. Additionally, only small sample amounts are required. A combination of needle type and $\mathrm{H}_{2} \mathrm{O}_{2}$-detecting glucose sensor has been considered as a potential design for in vivo purposes. During the past few years many efforts have been made to develop needle-type glucose sensors for in vivo applications (4-10). Gold (11) and platinum (12) were the most widely used material for constructing the working electrode of needle-type sensors. However, the high cost of production renders these electrodes unsuitable for construction as disposables.

For constructing an amperometric enzyme sensor for blood-sugar determination it is necessary to use diffusion limiting materials that are biocompatible. Biocompatibility is necessary to obviate blood clotting and the immune reaction. Diffusion limitation is necessary to extend the working range of the sensor. There are two kinds of biocompatible materials; active (positive) $(13,14)$ and inert (negative) $(15,16)$. Neither of these elicit an immune response. The positive type has a disadvantage in that components of biological fluids adhere to them. This acts as a diffusive barrier to the diffusion of the analyte into the biological layer of a biosensor and consequently reduces its response. 2-Methacryloyloxyethyl phosphorylcholine (MPC) is an inert biocompatible material (17), capable of reacting with $n$-butylmethacrylate (BMA) to produce a water-insoluble copolymer $(\mathrm{MB})$. The synthesis and biocompatibility of $\mathrm{MB}$ have been described previously (17-19). The structural formula of MPC-co-BMA is shown below. 


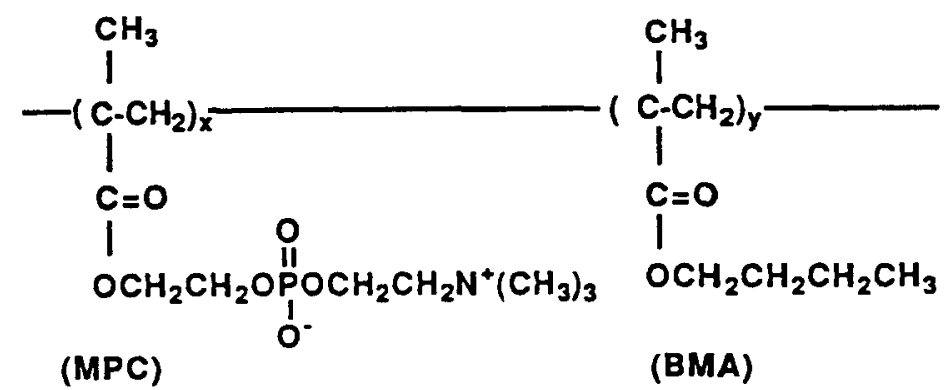

The dynamic range of a glucose sensor without a diffusion-limiting membrane was found to be less than $100 \mathrm{mg} / \mathrm{dL}(20)$. The glucose concentration of blood lies between 50 and $120 \mathrm{mg} / \mathrm{dl}$ for nondiabetics and can be as high as $600 \mathrm{mg} / \mathrm{dl}$ for diabetics (21). A diffusion-limiting membrane is necessary for extending the dynamic range of a glucose sensor so that glucose can be determined directly in undiluted blood. Cellulose acetate and its derivatives have been widely used for this purpose (22).

In this study a piece of a platinum-electroplated carbon stick was used to construct a needle-type $\mathrm{H}_{2} \mathrm{O}_{2}$-detecting glucose sensor. Electroplating platinum onto a carbon stick produced an inexpensive, reliable working electrode for constructing such a sensor. Three membranes were coated onto the working electrode of the sensor. At first a Nafion membrane was coated on the platinum to prevent interference caused by ascorbate and urate (23). Glucose oxidase was then immobilized onto the working electrode by a process including both crosslinking with glutaraldehyde and entrapment by a photocrosslinkable polyvinyl alcohol, PVA-SbQ $(24,25)$. Finally diffusion-limiting the effect was conferred and the sensor was made biocompatible by the MB-CTA membrane. The structure formula of PVA-SbQ is shown below followed by its photocrosslinking mechanism.<smiles></smiles> 


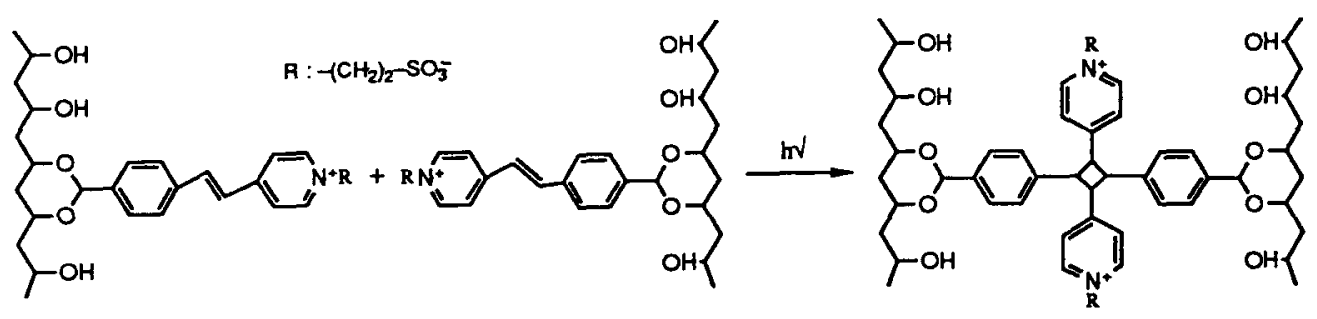

The response, reproducibility, selectivity, and stability of the sensor along with the effects of temperature, $\mathrm{pH}$, and metallic ions on response of the sensor were studied. The sensor was used to determine glucose in serum. The data obtained from the sensor was in good agreement $(r=0.9529)$ with that from a clinical autoanalyzer.

\section{EXPERIMENTAL}

\section{Materials and Instrumentation}

Glucose oxidase (EC 1.1.3.4) from Aspergillus niger, glucose, and imidazole, were from the Sigma Chem. Co. Nafion ${ }^{\oplus}$ perfluorinated ionexchange resin $(5 \% \mathrm{w} / \mathrm{v}$ in mixture of lower aliphatic alcohols and $10 \%$ water) was from the Aldrich Chem. Co., and was used as supplied. Cellulose triacetate was from Eastman Kodak Co. All the chemicals required for synthesizing $M B$ were obtained, purified, or prepared as described previously (17-19). Phosphate buffered saline (PBS) was prepared by dissolving $2.754 \mathrm{~g} \mathrm{NaCl}, 2.081 \mathrm{~g} \mathrm{KH}_{2} \mathrm{PO}_{4}$, and $0.477 \mathrm{~g} \mathrm{NaOH}$ in $1000 \mathrm{~mL}$ distilled water and adjusting the $\mathrm{pH}$ to 7.4 with $0.1 \mathrm{~N} \mathrm{NaOH}$ solution (26). Glucose solutions were prepared in PBS and allowed to stand for at least $24 \mathrm{~h}$ before use to equilibrate the $\alpha$ and $\beta$ anomers. Control serum was from Katayama Chem. Co. (Osaka, Japan). The glucose analysis kit based on glucose oxidase was from Wako Chem. Co. (Japan). All other chemicals used in this study were of the highest grade available and were used without further purification.

The batch-operated system was composed of a potentiostat, a circulating water bath, a water-jacketed glass reactor, a magnetic stirrer with stirring bar, and a chart recorder, as described previously (20). The hypodermic needle made of stainless steel (1.2 $\mathrm{mm}$ O.D., $1.0 \mathrm{~mm}$ I.D.) was obtained from Terumo Co. (Tokyo, Japan). Teflon-coated silver wire (0.127 mm O.D.) was from Nilaco Co. (Tokyo, Japan). The clinical autoanalyzer was a Beckman Glucose Analyzer II from the Beckman Instrument $\mathrm{Co}$. The electron microscope was a JSM-5400 Scanning Microscope from Jeol Co. (Tokyo, Japan). 


\section{Preparation of MB-CTA Solution}

MB was synthesized according to the method described previously (17-19). MB-CTA solution was prepared by mixing MB solution $(10 \% \mathrm{w} / \mathrm{v}$ in methanol) and CTA solution ( $3 \% \mathrm{w} / \mathrm{v}$ in 1,1,2,2-tetrachlorethane) in a $2: 3$ ratio.

\section{Evaluation of the Biocompatibility of MB-CTA Membrane}

Platelet-rich plasma (PRP) was prepared from citrated rabbit blood as described previously $(18,19)$. A CTA and the MB-CTA solution were cast onto a piece of $14 \mathrm{~mm}$ diameter telephthalate disk (Wako Chem. Co.) individually and air-dried at room temperature. The dry disks were immersed in the PRP for $1 \mathrm{~h}$ and then transferred to a saline solution containing $2.5 \%$ glutaraldehyde to reinforce the immobilization of bound platelets. The disks were rinsed, dried, coated with gold, and the surface examined by scanning electron microscopy.

\section{Preparation of Electrodes of the Sensor}

A piece of carbon stick $(0.5 \mathrm{~mm}$ diameter, $30 \mathrm{~mm} \mathrm{~L}$., PFC-41, Mitsubishi Pencil Co., Tokyo, Japan) was connected to copper wire by conductive silver paste (Dotite electroconductives, D-362, Fujikura Chem. Co., Tochii-Kan, Japan). The carbon stick was insulated with Teflon tubing, which was then stripped to form a cavity that exposed the carbon surface (27). This was achieved by putting a circular cut in the Teflon tubing 1 $\mathrm{mm}$ from the tip and then pulling the tubing out to create a cavity $0.5 \mathrm{~mm}$ wide. The carbon electrode and a piece of platinum wire were placed in a platinum electroplating solution (Pentanex 3LS, Electroplating Engineers of Japan Co., Tokyo, Japan). Electroplating was performed by applying a current of $-3 \mathrm{~mA}$ between the carbon electrode and the platinum wire for $5 \mathrm{~min}$ at $80^{\circ} \mathrm{C}$. The platinum-electroplated carbon electrode was used as the working electrode.

A cavity was created by the same operation on a piece of Tefloncoated silver wire $(0.127 \mathrm{~mm}$ O.D.). Silver was converted to $\mathrm{Ag} / \mathrm{AgCl}$ by dipping in a $\mathrm{H}_{2} \mathrm{O}_{2}-\mathrm{HCl}$ solution ( $1 \mathrm{M} \mathrm{H}_{2} \mathrm{O}_{2}: 1 \mathrm{M} \mathrm{HCl}, 1: 1$ ratio) and used as the reference electrode.

A disposable hypodermic needle made of stainless steel (O.D. 1.2 $\mathrm{mm}$, I.D. $1.0 \mathrm{~mm}$ ) was connected with copper wire by the conductive silver paste and used as the counter electrode.

\section{Construction of the Multilayer Membrane System}

Three membranes made up the multilayer system. Initially $2 \mu \mathrm{L}$ of Nafion solution was dropped into the cavity of the working electrode and 


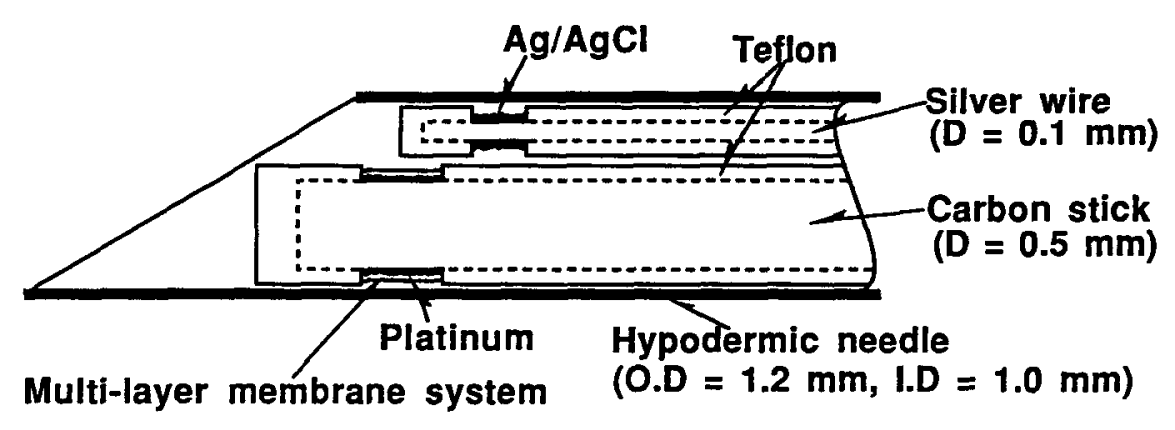

Fig. 1. Schematic diagram of the needle-type glucose sensor.

then dried at room temperature for $30 \mathrm{~min} .2 \mu \mathrm{L}$ of the enzyme solution composed of $1 \mathrm{mg}$ of GOD (135 U/mg), $5 \mathrm{mg}$ bovine serum albumn (BSA), $100 \mathrm{mg}$ distilled water, and $100 \mathrm{mg}$ PVA-SbQ, was then dropped into the cavity. The electrode was placed in a sealed dark box containing glutaraldehyde vapor and kept at room temperature for $12 \mathrm{~h}$ to complete the crosslinking reaction. The electrode was then exposed to a fluorescent lamp for $10 \mathrm{~min}$ to induce photocrosslinking of PVA-SbQ. Finally, $2 \mu \mathrm{L}$ MB-CTA solution was dropped into the cavity and dried for $30 \mathrm{~min}$ at room temperature. The electrodes were stored at $4^{\circ} \mathrm{C}$ in a dry state until use.

\section{Construction of the Needle Type Glucose Sensor}

The working and the reference electrodes were inserted into the hollow interior of the counter electrode. Epoxy resin was used to fix electrodes in position. The schematic diagram of the sensor is shown in Fig. 1.

\section{Determination of Glucose Concentration}

The electrode was immersed in PBS solution for $1 \mathrm{~h}$ to equilibrate the membrane system. The lead wires were then connected to the potentiostat and a potential of $600 \mathrm{mV}$ was applied. The base line was measured in PBS and glucose solutions were then injected into the PBS solution using a microsyringe. The response current following injection was recorded by a chart-recorder until the second steady state was achieved. Magnetic stirring was used during the operation to ensure homogeneity of the reacting solution. The difference between the baseline and the second steady state current was used to calculate the concentration of glucose in the sample according to a calibration curve.

Another calibration curve was taken by adding glucose solution into a heparinized whole blood that has been incubated at $37^{\circ} \mathrm{C}$ for $18 \mathrm{~h}$ to allow glycolysis (28). The concentration of glucose in serum and whole blood was determinated according to this calibration curve. 


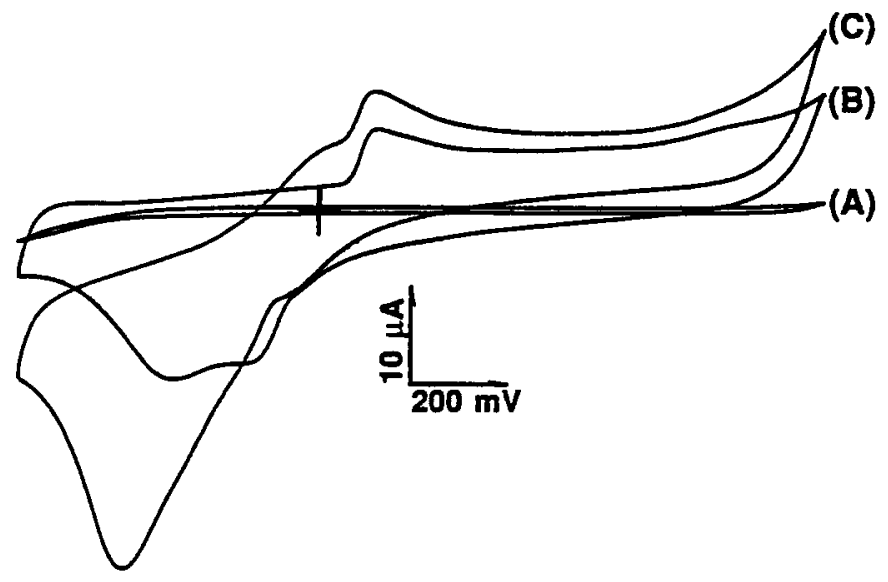

Fig. 2. Cyclic voltammogram of the electrode. Key: (A) Carbon stick as the working electrode, $\mathrm{Ag} / \mathrm{AgCl}$ as the reference electrode, and stainless-steel as the counter electrode in PBS, $\mathrm{pH} 7.4$, at $37^{\circ} \mathrm{C}$. (B) Platinum-electroplated carbon stick as the working electrode in PBS, pH 7.4 at $37^{\circ} \mathrm{C}$. (C) Platinum-electroplated carbon stick as the working electrode in PBS containing $1 \mathrm{mM} \mathrm{H}_{2} \mathrm{O}_{2}$, $\mathrm{pH} 7.4$, at $37^{\circ} \mathrm{C}$.

\section{RESULTS AND DISCUSSION}

\section{Determination of the Applied Potential}

The cyclic voltammograms of the electrodes using the carbon stick itself or the platinum-electroplated carbon stick as the working electrode, stainless steel as the counter electrode, and $\mathrm{Ag} / \mathrm{AgCl}$ as the reference electrode are shown in Fig. 2. After being electroplated with platinum the characteristic reducing peak of a platinum electrode, located at around $-400 \mathrm{mV}$, was clearly exhibited. This showed the possibility of using a platinum-electroplated carbon stick instead of a platinum wire as the working electrode. This would contribute to cost reduction in constructing a sensor. The plateau of this electrode after contacting with $\mathrm{H}_{2} \mathrm{O}_{2}$ ranged from $+400 \mathrm{mV}$ to $+700 \mathrm{mV}$. A potential of $+600 \mathrm{mV}$ was selected for this study.

\section{Biocompatibility of the MB-CTA Membrane}

After contacting with PRP for $1 \mathrm{~h}$ on the CTA membrane over 5000 platelets were found adsorbed to $1 \mathrm{~mm}^{2}$ of surface. On the MB-CTA membrane no more than 100 platelets were found per $1 \mathrm{~mm}^{2}$. Adherence of platelets are one of the initial steps in bloodclotting (17-19). Prevention 
of platelet adherence ensured the biocompatibility of the MB-CTA membrane. The biocompatibility of MPC and its copolymer with butyl methacrylate (MB) has been described previously $(17,18)$. The membrane from a mixture of MB and CTA shows good biocompatibility. Diffusion-limitation effect has also been reported for this material (29). The biocompatibility prevents the electrode surface from being fouled by bloodclotting, an action that contributed to the stable response of the sensor in blood. The diffusion-limitation makes the measurement of glucose in undiluted blood possible.

\section{Membrane Function and Their Effects on Response of the Sensor}

Three layers were included in the multilayer membrane system. The innermost layer was a Nafion membrane. Nafion is a negatively charged polymer and therefore prohibits the passage of negatively charged interfering materials, such as ascorbate and urate, to the working electrode (23). The middle layer was the immobilized glucose oxidase membrane. Enzyme immobilization was achieved by a double crosslinking method that used a photo crosslinkable polyvinyl alcohol compound (PVA-SbQ) in conjunction with a chemical crosslinking compound (glutaraldehyde). Glucose oxidase was crosslinked by glutaraldehyde and then entrapped by PVA-SbQ. This allowed firm entrapment of the enyzme and, as a result, good stability of the sensor (20). The outermost layer was the MBCTA membrane. This membrane had three functions. The first was to act as a protective ultrafiltration membrane by allowing only small molecules to pass through it and preventing large ones, such as proteins and other enzymes in the sample solution, from contacting with the enzyme membrane. The second function was to reduce the permeating rate of glucose into the enzyme membrane. This action can effectively extend the dynamic range of the sensor and makes direct determination of glucose in blood possible. The third function was to confer the sensor with biocompatibility. This also increased the stability of the sensor in blood.

The responses of the sensor to ascorbate $(2 \mathrm{mg} / \mathrm{dL})$ and urate $(10$ $\mathrm{mg} / \mathrm{dL}$ ) are shown in Fig. 3. The bare electrode responded strongly to both of them. The response to ascorbate was reduced to zero and the response to urate was reduced to about $0.3 \%$ after the working electrode was covered by the Nafion membrane. It was further reduced to zero after being covered by the immobilized enzyme and the MB-CTA membrane. The normal concentration of ascorbate and urate in blood is $0.4-1.5 \mathrm{mg} / \mathrm{dL}$ and $1.5-1.8 \mathrm{mg} / \mathrm{dL}$, respectively (21). The ability of the multi-layer membrane to restrict the penetration of interfering materials in blood can improve the accuracy of the sensor. 


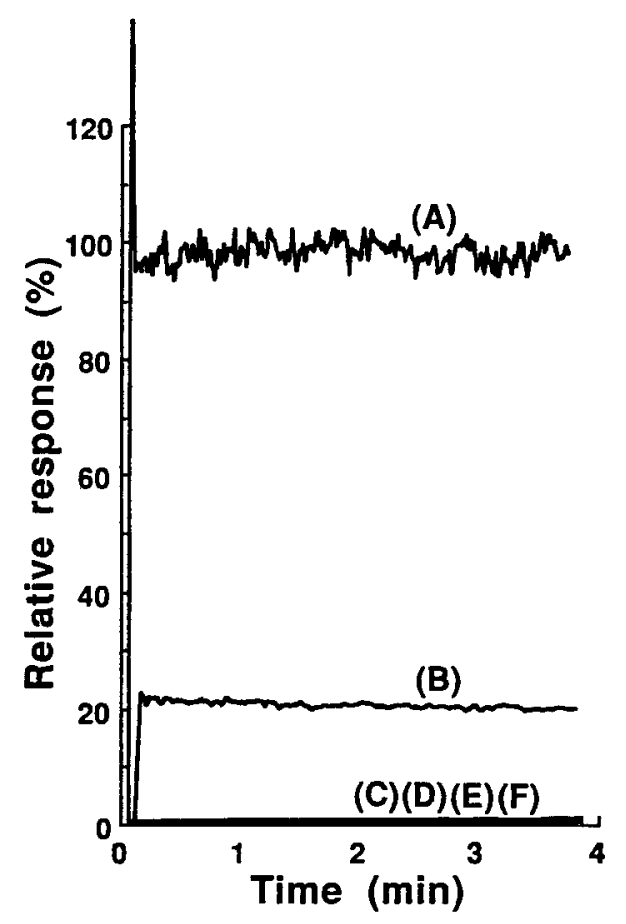

Fig. 3. Effects of each kind of membrane on response of the sensor to 10 $\mathrm{mg} / \mathrm{dL}$ uric acid and $2 \mathrm{mg} / \mathrm{dL}$ ascorbic acid. Experiments were conducted in PBS, $\mathrm{pH} 7.4$, at $37^{\circ} \mathrm{C}$. Key: (A) Bare electrode to urate. (B) Bare electrode to ascorbate. (C) (D) Nafion coated electrode to urate and ascorbate, respectively. (E) (F) Nafion, GOD, and MB-CTA coated electrode to urate and ascorbate, respectively.

\section{Calibration Curves of the Sensor}

Calibration curves of the sensor are presented in Fig. 4. The sensor with Nafion and the immobilized GOD membrane on the working electrode showed a dynamic range of $1-40 \mathrm{mg} / \mathrm{dL}$ glucose. The dynamic range was increased to 5-600 mg/dL glucose, which is broad enough for most blood samples in a clinic laboratory, after the working electrode was further coated with MB-CTA membrane. The ability to increase the dynamic range of the sensor verified the diffusion-limiting effect of the MB-CTA membrane. This makes the determination of glucose in undiluted blood possible. The calibration curve of the sensor in glycolyzed serum is also shown in Fig. 4. The response intensity in glycolyzed serum was about $56 \%$ of that in PBS. This calibration curve was used to calculate the glucose concentration in control serum and human serum. 


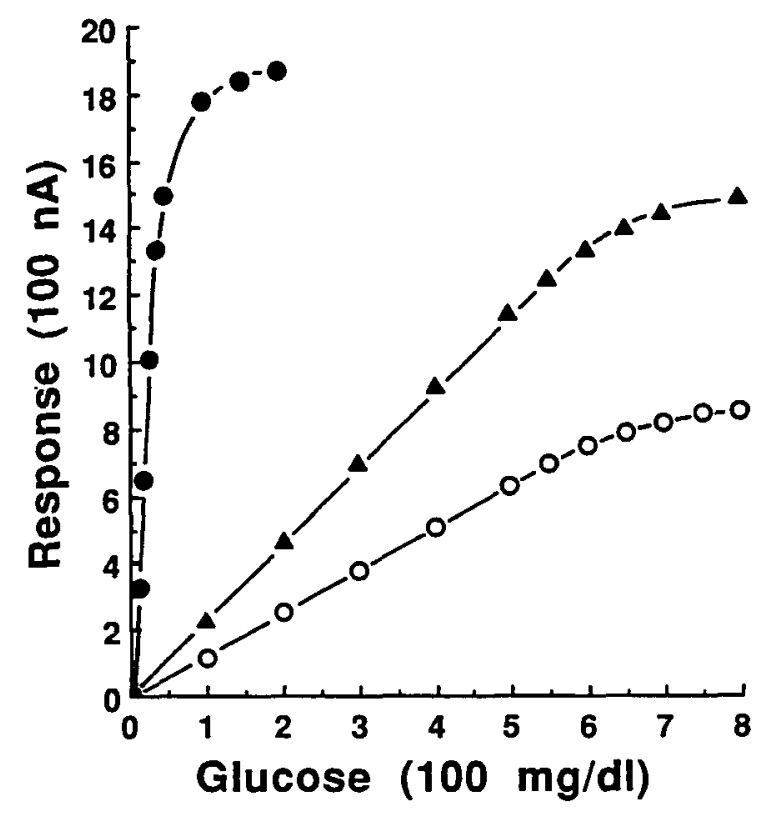

Fig. 4. Calibration curves of the sensor. Experiments were conducted at $37^{\circ} \mathrm{C}$. Key: $(\bullet)$ Nafion and GOD coated electrode in PBS. ( $\triangle$ ) Nafion, GOD and MB-CTA coated electrode in PBS. (O) Nafion, GOD and MB-CTA coated electrode in glycolyzed serum.

\section{Effect of Temperature \\ on Response of the Sensor}

The response curves of the sensor at several temperature are shown in Fig. 5. The response intensity of the sensor increased with temperature from $2-50^{\circ} \mathrm{C}$ and the responses at lower temperatures remained unchanged after being tested at $50^{\circ} \mathrm{C}$. If the respoonse intensity at $37^{\circ} \mathrm{C}$ is taken as 100 , the response at $2,10,20,30,34,40$, and $50^{\circ} \mathrm{C}$ were 19.5 , $32.1,52.5,76.9,89.4,109.5$, and 148.3 , respectively. The thermostability of the sensor and the free GOD in solution were also investigated. After being incubated at $50^{\circ} \mathrm{C}$ for $2 \mathrm{~h}$, the response of the sensor remained unchanged but the free GOD in solution lost $91 \%$ of its original activity. These results suggested that the thermostability of GOD was significantly increased after being immobilized by the process adopted in this study. This figure also shows the response time of the sensor. The time required to reach the second steady state was also temperature dependent. Longer time was needed at lower temperature, but at $37^{\circ} \mathrm{C}$, however, less than $120 \mathrm{~s}$ was required to obtain a $95 \%$ response. 


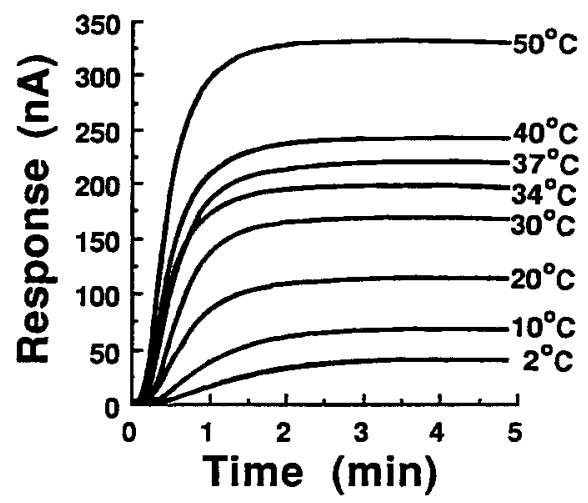

Fig. 5. Response curves of the sensor to $100 \mathrm{mg} / \mathrm{dl}(5.55 \mathrm{mM})$ glucose under various temperatures in PBS, $\mathrm{pH} 7.4$.

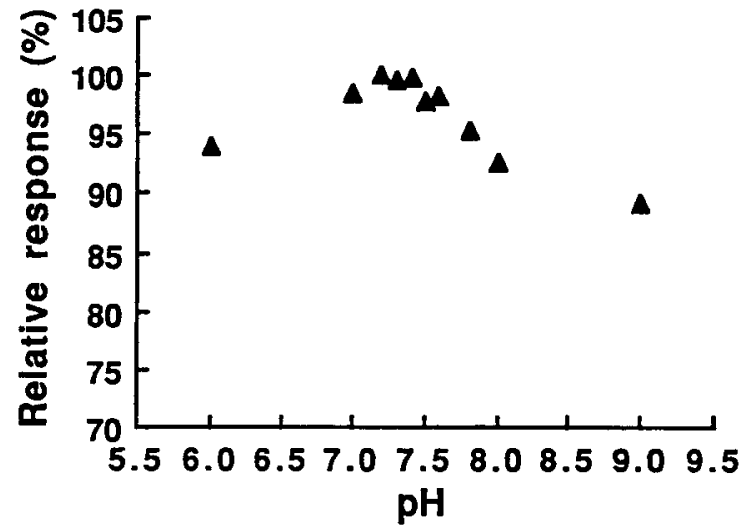

Fig. 6. Effect of $\mathrm{pH}$ on response of the sensor at $37^{\circ} \mathrm{C}$ in $50 \mathrm{mM}$ phosphate buffer.

\section{Effects of $\mathrm{pH}$ and Metallic Ions \\ on Response of the Sensor}

The effect of $\mathrm{pH}$ is shown in Fig. 6. Phosphate buffer covering the $\mathrm{pH}$ range from 6.0-9.0 were used. The highest response was obtained at $\mathrm{pH}$ 7.2. The optimal $\mathrm{pH}$ of free GOD in solution is 5.6 and its activity decreases at $\mathrm{pH}$ lower than 2.0 or higher than 8.0 has been reported (30). The optimal $\mathrm{pH}$ of the immobilized GOD was promoted to 7.2, which is close to the $\mathrm{pH}$ of blood. The promotion of optimal $\mathrm{pH}$ after the GOD being immobilized by the process used in this study contributed to a higher response of the sensor in blood. The $\mathrm{pH}$ of blood is located between 7.2 and $7.6(21)$. The difference of response intensities in this range is less than $3 \%$. 
Table 1

Effect of Metallic Ions on Response of the Sensor

\begin{tabular}{llcc}
\hline Metallic ion & Metallic salts & $\begin{array}{c}\text { Conc., } \\
\mu M\end{array}$ & $\begin{array}{c}\text { Relative } \\
\text { response, \% }\end{array}$ \\
\hline None & & & 100.0 \\
$\mathrm{Ca}^{2+}$ & $\mathrm{Ca}\left(\mathrm{NO}_{3}\right)_{2}$ & 2750 & 98.9 \\
$\mathrm{Mg}^{2+}$ & $\mathrm{Mg}\left(\mathrm{NO}_{3}\right)_{2} \cdot 6 \mathrm{H}_{2} \mathrm{O}^{* *}$ & 1235 & 98.7 \\
$\mathrm{Mg}^{2+}$ & $\mathrm{MgSO}_{4}^{* \star}$ & 1235 & 99.0 \\
$\mathrm{Zn}^{2+}$ & $\mathrm{ZnSO}_{4} \cdot 7 \mathrm{H}_{2} \mathrm{O}$ & 30 & 100.4 \\
$\mathrm{Fe}^{3+}$ & $\mathrm{Fe}\left(\mathrm{NO}_{3}\right)_{3}$ & 30 & 99.3 \\
$\mathrm{Cu}^{2+}$ & $\mathrm{CuSO} \cdot 5 \mathrm{H}_{2} \mathrm{O}$ & 25 & 92.3 \\
\hline
\end{tabular}

* The concentrations were slightly higher than those in serum (13).

** To verify the difference between nitrate and sulfate. Experiments were done in $10 \mathrm{mM}$ imidazole buffer, $\mathrm{pH} 7.4$, at $37^{\circ} \mathrm{C}$.

The effects of some metallic ions are shown in Table 1. Calcium, magnesium, iron, zinc, and copper are major metallic ions in serum (21). Among them, at the concentration a little higher than that usually encountered in blood, only the cooper ion caused a reduction of $7.7 \%$ to the response of the sensor.

\section{Selectivity, Reproducibility, and Stability of the Sensor}

The selectivity of this sensor was tested by determining several mono- and disaccharides at the same concentration as glucose. This sensor showed relative responses of $100,3.4,3.1$, and 6.1 to glucose, galactose, maltose, and mannose, respectively, but did not respond to lactose, sucrose, and fructose as shown in Fig. 7. The specificity of GOD has been reported as $100,0.14,0.19$, and 0.98 to glucose, galactose, maltose, and mannose, respectively, but no reaction to fructose, lactose, and sucrose (31). The selectivity of the sensor was in accordance with the previous report (31), but the responses to galactose, maltose, and mannose were higher than that described. The GOD used in this study, according to the data-sheet from the supplier, also contained impurities including maltase, glycogenase, invertase, amylase, and galactose oxidase. It is likely that enzyme impurities were chiefly responsible for the stronger responses to galactose, maltose, and mannose. However, sugars other than glucose exist only at very low concentration in biological fluids. The errors caused by these sugars would be negligible.

Reproducibility of the sensor was investigated by repeatedly determining glucose in the same glucose solution. On the $5 \mathrm{~d}$ after the sensor was made, the relative error for 33 measurements was $2.84 \%$. 


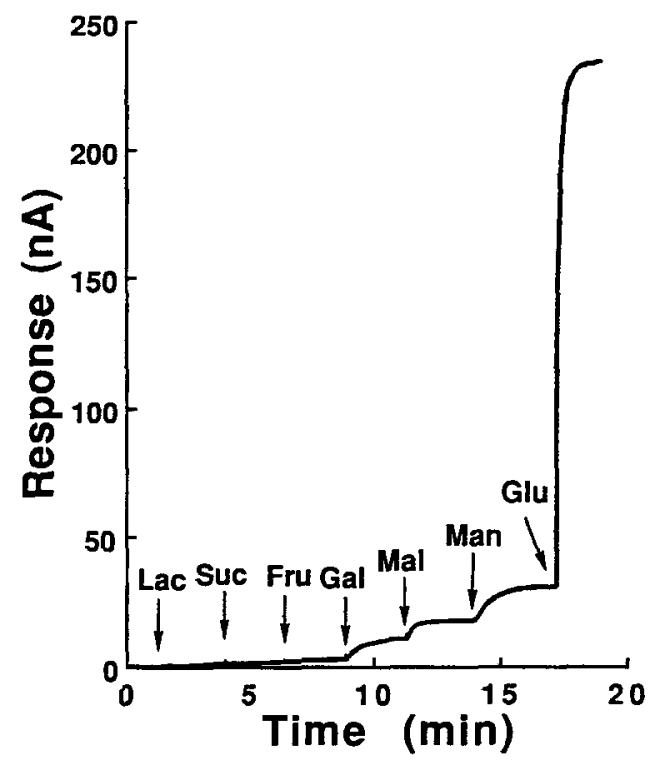

Fig. 7. Response of sensor to various sugars $(5.55 \mathrm{mM})$ at $37^{\circ} \mathrm{C}$ in $\mathrm{PBS}$, pH 7.4.

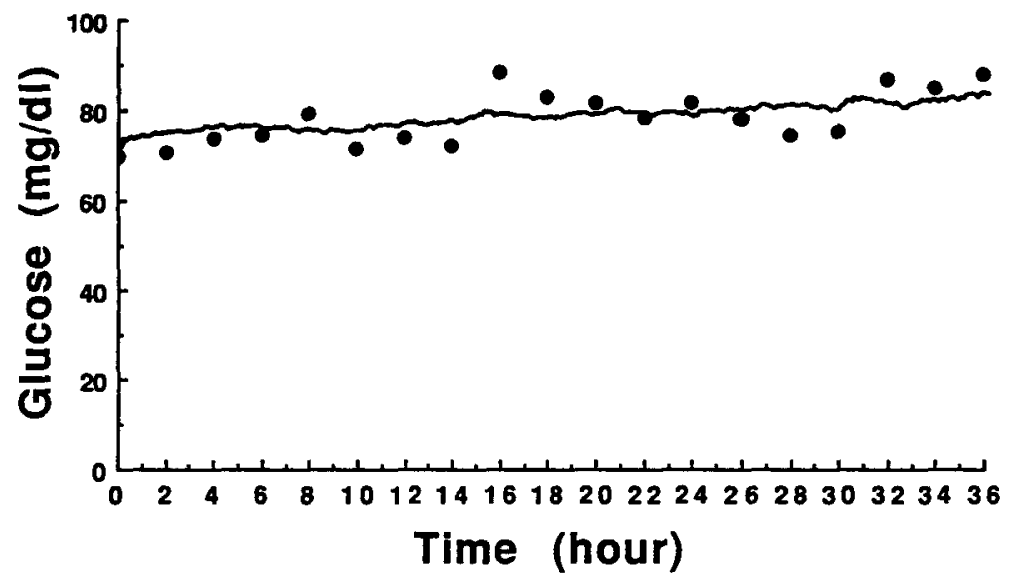

Fig. 8. Response of the sensor in control serum at $37^{\circ} \mathrm{C}(\mathrm{m})$ and the data from GOD assay kits ( $\bullet$ ).

Figure 8 shows the response of the sensor in control serum over a period of $36 \mathrm{~h}$. The sensor showed a stable response and was in good agreement with the data from the GOD assay kit by comparative assays. In some cases the sensor maintained a stable response for over $72 \mathrm{~h}$. In most cases the response decreased at about $40-50 \mathrm{~h}$ and the multilayer membrane system was found to have folded, when examined under the microscope. 


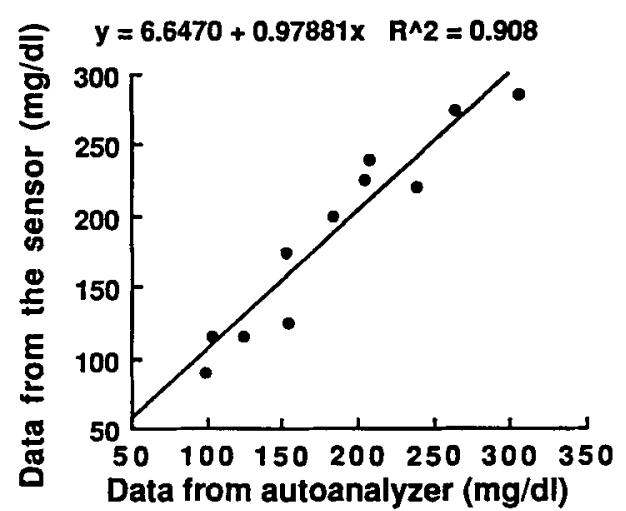

Fig. 9. Correlation between glucose concentrations in serum samples measured by an autoanalyzer $(X)$ and the glucose sensor $(Y)$. $(Y=0.9788 X+6.6470$. $r=0.9529 . n=11$ ).

\section{Determination of Glucose in Serum}

The sensor was situated in the glycolyzed serum to obtain the baseline current. It was then transferred to the serum sample to achieve the second steady state current. The difference was used to calculate the glucose concentration in the sample according to the calibration curve obtained in glycolyzed serum. The serum samples were determined with both the sensor and a glucose autoanalyzer. Correlation between the results from the two methods is presented in Fig. 9. The correlative coefficient was $0.9529(Y=0.9788 X+6.6470, n=11)$.

\section{CONCLUSION}

A needle-type amperometric glucose sensor was constructed. A piece of platinum-electroplated carbon stick was used as the working electrode, $\mathrm{Ag} / \mathrm{AgCl}$ as the reference electrode, and a disposable hypodermic needle made of stainless steel as the counter electrode. Electroplating of platinum onto the carbon stick offered a mass-producible, inexpensive, but reliable process for obtaining a working electrode. In addition, a large surface area and accordingly a strong response was obtained by the electroplating process. The platinum-electroplated carbon showed a cyclic voltammogram characteristic for a platinum wire. It also showed a plateau over a wide potential range with $\mathrm{H}_{2} \mathrm{O}_{2}$. These results ensured the possibility of using it to prepare $\mathrm{a}_{2} \mathrm{O}_{2}$-sensing electrode. A process including both crosslinking by glutaraldehyde and entrapment by a photocrosslinkable polymer, PVA-SbQ, was used to immobilize the enzyme. GOD was firmly immobilized and a stable response was consequently 
achieved. The membrane of MB-CTA possesses diffusion-limiting capability and the ability to prevent platelets from adsorbing. It conferred the sensor with biocompatibility and a wide working range. This action contributed a stable response and the ability of determining glucose in undiluted blood to the sensor. The combination of a good electrode, an effective process for enzyme immobilization, and a functional biocompatible membrane with diffusion-limiting capability produced good sensors that can accurately determine glucose in undiluted blood. Application of this sensor for in vivo purpose is now progressing in this laboratory.

\section{ACKNOWLEDGMENT}

The Ministry of Education of Taiwan, R.O.C. is acknowledged for sponsoring this study. The authors wish to thank R. Wilson and N. Mionetto for their assistance with the English and helpful discussions. Colleagues in The Department of Agricultural Chemistry, National Taiwan University, are also appreciated for helping Chien-Yuan Chen with his teaching and administration responsibilities at National Taiwan University during his study in Japan.

\section{REFERENCES}

1. Gunasingham, H., Tan, C. H., and Aw, T. C. (1990), Anal. Chim. Acta 234, 321.

2. Bardeletti, G., Sechaud, F., and Coulet, P. R. (1991), in Biosensor: Principles and applications, Blum, L. J. and Coulet, P.R., eds., pp. 7-45.

3. Guibault, G. G. and Lubrano, G. J. (1973), Anal. Chim. Acta 64, 439.

4. Shichiri, M., Kawamori, R., Hakui, N., Yamasaki, Y., and Abe, H. (1984), Diabetes 33, 1220.

5. Clarmont, D. J., Penton, C., and Pickup, J. C. (1986), J. Biomed. Eng. 8, 272.

6. Matthews, D. E. R., Bown, E., Beck, T. W., Plotkin, E., Lock, L., Gosden, E., and Wickham, M. (1988), Diabetic Med. 5, 248.

7. Velho, G., Frogel, P., Sternberg, R., Thevenot, D. R., and Reach, G. (1989), Diabetes 38, 164.

8. Koudelka, M., Rohner-Jeanrenaud, F., Terrettaz, J., Bobbioni-Harsch, E., de Rooij, N. F., and Jeanrenaud, B. (1991), Biosens. Bioelec. 6, 31.

9. Moatti-Sirat, D., Capron, F., Poitout, V., Reach, G., Bindra, D. S., Zhang, Y., Wilson, G. S., and Thevenot, D. R. (1992), Diabetologia 3, 35.

10. Moatti-Sirat, D., Velho, G., and Reach, G. (1992), Biosens. Bioelec. 7, 345.

11. Neuburger, G. G. and Johnson, D. C. (1987), Anal. Chem. 59, 150.

12. Neuburger, G. G. and Johnson, D. C. (1987), Anal. Chem. 59, 204.

13. Yui, T., Kataoka, K., Sakurai, Y., Aoki, T., Sanui, K., and Ogata, N. (1989), Biomaterials 9, 225. 
14. Lenk, T. J., Ratner, B. D., Gendreau, R. M., and Chittur, K. K. (1989), J. Biomed. Mater. Res. 23, 549.

15. Murabayashi, S., Kambic, H., Harasaki, H., Morimoto, T., Yozu, R., and Nose, Y. (1985), Trans. Am. Soc. Artif. Intern. Organs 31, 50.

16. Kottke-Marchant, K., Anderson, J. M., Umemura, Y., and Merchant, R. E. (1989), Biomaterials 10, 141.

17. Ishihara, K., Ueda, Y., and Nakabayashi, N. (1990), Polym. J. 22, 355.

18. Ishihara, K., Aragaki, R., Ueda, T., Watanabe, A., and Nakabayashi, N. (1990), I. Biomed. Mater. Res. 24, 1069.

19. Abe, L. (1990), B.S. thesis, Toho University, Japan.

20. Chen, C-Y., Gotoh, M., Makino, H., Su, Y-C., Tamiya, E., and Karube, I. (1992), Anal. Chim. Acta 265(1), 5.

21. Kanai, I. and Kanai, M. (1983), Clinical Laboratory Methods and Diagnosis, Kobunsha Publishing Co., Seoul, R.O.K.

22. Ikeda, S., Ishida, M., Ito, K., Ichikawa, K., Yukawa, T., Okkura, K., Nakao, A., Ichihashi, H., Kondo, T., and Kojima, H. (1987), The Chem. Soc. Japan 3, 507.

23. Kristensen, E. W., Kuhr, W.G., and Wightman, R. M. (1987), Anal. Chem. $59,1752$.

24. Ichimura, K. and Watanabe, S. (1982), J. Polym. Sci., Polym. Chem. Ed. 20, 1419.

25. Ichimura, K. (1984), J. Polym. Sci., Polym. Chem. Ed. 22, 2817.

26. Perrin, D.D. and Dempsey, B. (1981), Buffers for $p H$ and Metal lon Control, Kodanska Publishing Co., Tokyo, Japan.

27. Bindra, D. S., Zhang, Y., and Wilson, G. S. (1991), Anal. Chem. 63, 1692.

28. Claremont, D. J., Penton, C., and Pickup, J. C. (1986), J. Biomed. Eng. 8, 272.

29. Chen, C-Y., Ishihara, K., Tamiya, E., Su, Y-C., Nakabayashi, N., and Karube, I. (1992), Electroanalysis, in press.

30. Maruo, B. and Tamiya, N., eds., (1982), Enzyme Handbook, Asakura Publisher Co., Tokyo, Japan.

31. Keilin, D. and Hartree, E. F. (1952), Biochem. J. 50, 331. 